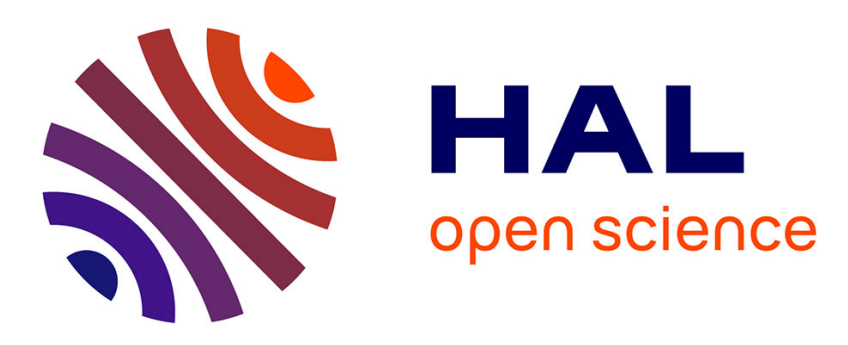

\title{
Effects of foliar nutrients and environmental factors on site productivity in Pinus pinaster Ait. stands in Asturias (NW Spain)
}

Álvarez-Álvarez, Elías Khouri, Cámara-Obregón, Castedo-Dorado, Barrio-Anta

\section{To cite this version:}

Álvarez-Álvarez, Elías Khouri, Cámara-Obregón, Castedo-Dorado, Barrio-Anta. Effects of foliar nutrients and environmental factors on site productivity in Pinus pinaster Ait. stands in Asturias (NW Spain). Annals of Forest Science, 2011, 68 (3), pp.497-509. 10.1007/s13595-011-0047-5 . hal00930782

\section{HAL Id: hal-00930782 https://hal.science/hal-00930782}

Submitted on 1 Jan 2011

HAL is a multi-disciplinary open access archive for the deposit and dissemination of scientific research documents, whether they are published or not. The documents may come from teaching and research institutions in France or abroad, or from public or private research centers.
L'archive ouverte pluridisciplinaire HAL, est destinée au dépôt et à la diffusion de documents scientifiques de niveau recherche, publiés ou non, émanant des établissements d'enseignement et de recherche français ou étrangers, des laboratoires publics ou privés. 


\title{
Effects of foliar nutrients and environmental factors on site productivity in Pinus pinaster Ait. stands in Asturias (NW Spain)
}

\author{
Pedro Álvarez-Álvarez • Elías Afif Khouri • \\ Asunción Cámara-Obregón . \\ Fernando Castedo-Dorado • Marcos Barrio-Anta
}

Received: 31 May 2010 / Accepted: 20 November 2010/Published online: 7 April 2011

(C) INRA and Springer Science+Business Media B.V. 2011

\begin{abstract}
- Background The effects of foliar nutrients and environmental variables on site productivity in Maritime pine (Pinus pinaster Ait.) stands in Asturias (NW Spain) were studied. - Methods Site productivity was evaluated by means of site index. The environmental characteristics considered included physiographic, edaphic and climatic variables. Two different statistical analyses were carried out to determine the key factors affecting site productivity: the CHAID procedure and parametric regression techniques.

- Results The regression trees obtained by applying the CHAID algorithm separately to each type of variable revealed the order of importance of the environmental factors. In addition, the variables corresponding to the first level of branches of the CHAID regression trees were consistent with those identified by parametric regression. According to the parametric regression model, a physical soil characteristic (soil depth) and a climatic characteristic (mean summer temperature) were the most important
\end{abstract}

Handling Editor: Matthias Dobbertin

P. Álvarez-Álvarez $(\bowtie) \cdot$ E. A. Khouri · A. Cámara-Obregón ·

M. Barrio-Anta

Department of Biology of Organisms and Systems,

Escuela Politécnica de Mieres, University of Oviedo,

Campus Universitario de Mieres,

C/Gonzalo Gutiérrez Quirós S/N,

33600 Mieres, Spain

e-mail: alvarezpedro@uniovi.es

F. Castedo-Dorado

Department of Engineering and Agricultural Sciences.

Escuela Superior y Técnica de Ingeniería Agraria,

University of León,

Avda. de Astorga S/N,

24400 Ponferrada, Spain variables for explaining site productivity in the region. Foliar concentrations of phosphorus and elevation were not significant factors in the parametric regression analysis (although considered key factors when foliar nutrients and physiographic variables were analyzed separately).

- Conclusion Although the percentage variability in SI explained by the best parametric model was not very high $(45 \%)$, the model is parsimonious and provides robust estimates of the spatial distribution of this variable. The results obtained provide further information about the ecology of this species in Asturias, and represent an important tool in forest management, especially for afforested areas.

Keywords Pinus pinaster - Site index · Foliar nutrients . Environmental factors . CHAID procedure .

Parametric regression

\section{Introduction}

Maritime pine is one of the most important tree species in Spain, in terms of surface cover and wood production. The species occupies an area of 1,200,000 ha, which represents $8 \%$ of the total forest area in Spain. The current volume over bark in forests of this species represents $16 \%$ of the total Spanish timber stock, and about $31 \%$ of the annual harvested volume (MARM 2008).

Maritime pine is also an important forest species in the region of Asturias (NW Spain), where it occupies a total surface area of 20,844 ha (5\% of the total forest area), with an average harvested volume of $74,250 \mathrm{~m}^{3}$ year $^{-1}$, which represents $10.4 \%$ of the total volume harvested annually (MARM 2008). The species grows in even-aged stands, derived from plantations or natural regeneration after clear- 
cutting or wildfire. The current rotation age is $30-40$ years, although older stands are common as a result of a lack of adequate management.

The area occupied by maritime pine in the region has increased in recent decades because the species has been widely used in afforestation programmes, for three main reasons: (i) its ability to grow in very poor soils and under prolonged drought, (ii) its high growth rate under oceanic climate conditions, and (iii) the high sensitivity of alternative species used in afforestation (mainly Pinus radiata and Eucalyptus globulus) to some pests and diseases. This species was planted in Asturias at an average rate of 400 ha per year between 1993 and 2007, i.e., 15\% of the total area planted in the region in the period.

Practical methods of site quality estimation are required to facilitate decisions with regard to species selection in afforestation, and also to enable prediction of the expected volume growth rate. The most common indicator used to characterize and classify site quality and to estimate potential productivity is the site index (SI), defined as the expected average height of dominant (or dominant and codominant) trees at a specific reference age (Clutter et al. 1983). This site quality indicator is commonly used because it is easy to interpret, is of high productive significance, and is of practical use in the correct application of forest growth models.

Site index can be inferred from past growth of the dominant or codominat trees in a specific site. However, when the species (or stand type) of interest is not present in a specific area and knowledge of the SI is required for management purposes, it must be inferred through indirect methods that relate site index to biophysical site variables (e.g., Rayner 1992).

Many efforts have been made to estimate the stand site index of a particular species by use of site factors as explanatory variables. Many of those studies have dealt with the problem by considering only certain types of variables. For instance, Lebourgeois (2007) used only climatic variables; Monserud et al. (1990) used both soil and topographic variables; Rubio and Sánchez-Palomares (2006) used topographic and climatic variables. Nevertheless, attempts to predict site quality from a small number of variables have usually proven unsuccessful (e.g., Rayner 1992), except where one factor is of overriding importance in explaining inter-site or inter-annual variation in growth (e.g., Snowdon and Waring 1991). The combination of information on climatic, soil, and topographic characteristics, together with the foliar nutrient status has provided more accurate results (Battaglia and Sands 1997, Chen et al. 1998, Fontes et al. 2003, Romanyà and Vallejo 2004), although the information required is more expensive and difficult to acquire.

The objective of the present study was to examine how the productive capacity of maritime pine stands in Asturias is related to foliar nutrient status and environmental (climatic, physiographical and edaphic) properties. The results of the study should help forest managers make decisions with regard to species selection in new afforestations, and choose the most appropriate management practices for established stands.

\section{Materials and methods}

\subsection{Characteristics of the study area}

Maritime pine in Asturias is mainly distributed in the foothills of mountains close to the coast (Fig. 1). The altitude of most of the study sites is moderate, ranging between 300 and $700 \mathrm{~m}$, and the terrain is hilly, with slope gradients often exceeding $40 \%$. The average annual temperature is $13^{\circ} \mathrm{C}$, and the average annual precipitation is $1130 \mathrm{~mm}$.

The soils in most of the stands are characterized by moderate or shallow depth, high organic matter content in the upper horizon, low exchangeable base cation, and high or moderate acidity $(\sim \mathrm{pH} 4)$, except in eastern Asturias, where most of the rocks are basic. The rocks were classified as Ustorthent and Ustochrept (Soil Survey Staff 1999), and were mainly developed on feldspar sandstone (52 stands) and also on phyllite (12) and conglomerate (9). With regard to the texture, the content of silt and coarser-textured particles is slightly higher in soils developed on sandstone rocks than in soil developed on phyllites and conglomerates.

\subsection{Data collection}

The data set was obtained from a network of 73 experimental plots established in pure even-aged stands by researchers at the University of Oviedo. The plots were located throughout the area of distribution of the species in the study region, and were entirely subjectively selected to represent the existing range of ages, stand densities and site qualities. The widespread sampling of plots also guaranteed that a wide range of sites were covered in relation to topographic, climatic and soil characteristics, as well as foliar nutrition status.

The plot size ranged from 700 to $900 \mathrm{~m}^{2}$, depending on stand density, in order to achieve a minimum of 30 trees per plot. All the trees in each sample plot were labelled with a number. Diameter at breast height and total height were measured to the nearest $0.1 \mathrm{~cm}$ and $0.1 \mathrm{~m}$ respectively, in all trees included in the sample plot. When dealing with plantations, plot age ( $t$, years) was determined by establishing the date when the afforestation was carried out. Otherwise, the average age of six representative trees in 
Fig. 1 Distribution of maritime pine in Europe and Asturias (inset)

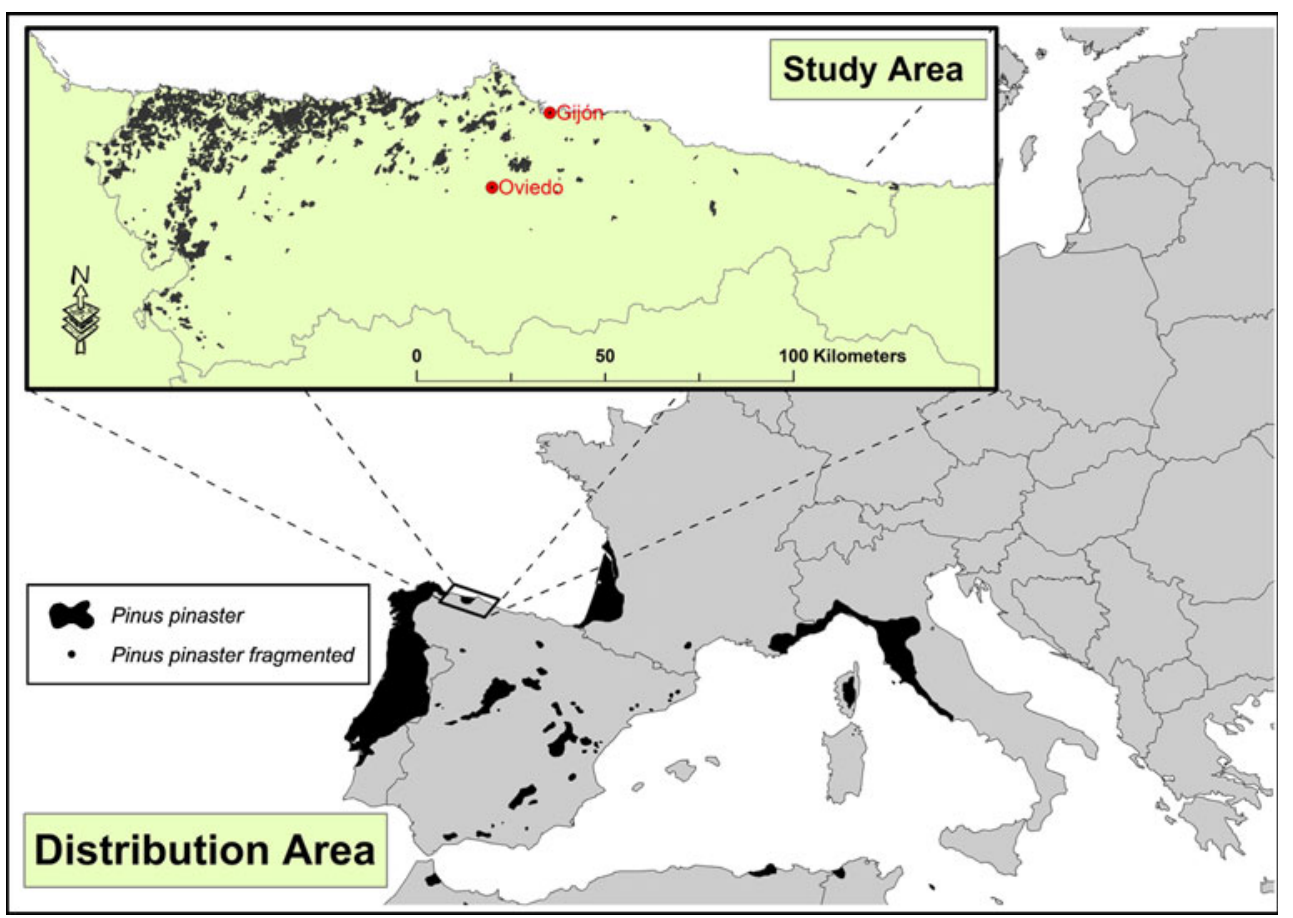

the plot was selected as the representative age. The dominant height $\left(H_{0}\right.$, metres) in each plot was calculated as the mean height of the 100 thickest trees per hectare, and site index (SI, defined as the dominant height of the stand, in metres, at a reference age of 20 years), was obtained from a site quality system (Fig. 2). This system is an algebraic difference equation based on the function proposed by Hossfeld (Hossfeld 1822), and was selected as the best solution to describe the dominant height growth of maritime pine stands in Asturias from among the six models used by Barrio et al. (2006). The dummy variables method (Cieszewski et al. 2000), in which a continuous-time autoregressive error structure is considered for accounting

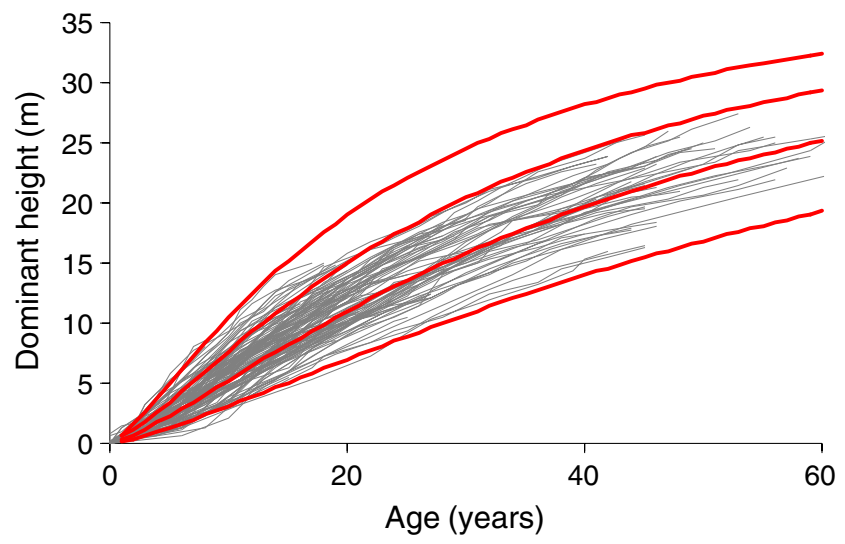

Fig. 2 Dominant height growth curves for SI values of 7, 11, 15 and $19 \mathrm{~m}$ at a reference age of 20 years, overlaid on the trajectories of the observed heights over time for eq. 1 for autocorrelation, was used to estimate the model parameters. The dynamic equation (Eq. [1]) used for site index estimation is expressed as follows:

$S I=\frac{41.40}{\left[1-\left(1-\frac{41.40}{H_{0}}\right)\left(\frac{t}{20}\right)^{1.325}\right]}$

In each plot, soil depth was determined at a minimum of three randomly selected points, with a Dutch auger. Five soil samples were taken with the same auger from depths of between 0 and $20 \mathrm{~cm}$, and were combined to make a bulk soil horizon. The samples were air-dried, crumbled, finely crushed and sieved with a $2 \mathrm{~mm}$ screen before analysis, in duplicate. Particle-size distribution was determined by the pipette method, and sodium hexametaphosphate and $\mathrm{Na}_{2} \mathrm{CO}_{3}$ were used to disperse the samples (Gee and Bauder 1996). The $\mathrm{pH}$ was measured in $\mathrm{H}_{2} \mathrm{O}$ with a glass electrode in a suspension of soil and water (1:2.5), and the electrical conductivity was measured in the same extract (diluted 1:5). Organic matter was determined by the ignition method. Total $\mathrm{N}$ was determined by a Kjeldahl digest. Available $\mathrm{P}$ was determined colorimetrically with Mehlich 3 reagent. Exchangeable cations (K, Mg, $\mathrm{Na}$ and Ca) extracted with $1 \mathrm{M} \mathrm{NH} 4 \mathrm{Cl}$, and exchangeable aluminium extracted with $1 \mathrm{M} \mathrm{KCl}$, were determined by atomic absorption/emission spectrophotometry. The effective cation exchange capacity (ECEC) was calculated as the sum of the values of the latter two measurements (sum of exchangeable cations and exchangeable $\mathrm{Al}$ ). 
Needle samples of current-year growth were collected in September from the upper third of the crowns of two dominant felled trees and from another two well-formed trees chosen at random in each plot. The samples were combined to provide a composite sample for each plot. The composite samples were washed with distilled water, ovendried at $70^{\circ} \mathrm{C}$ for 48 hours, milled and sieved with a $0.5 \mathrm{~mm}$ screen, before analysis, in duplicate. The concentrations of $\mathrm{P}$ and boron (B) were determined by colorimetric analysis following combustion for 4 hours in a muffle furnace at $450^{\circ} \mathrm{C}$, and dissolution of the ashes with $6 \mathrm{~N}$ $\mathrm{HCl}$. The $\mathrm{Ca}, \mathrm{Mg}$ and $\mathrm{K}$ were analyzed by atomic spectrophotometry in the same extract (Jones et al. 1991). Nitrogen (organic and ammonia) was determined by Kjeldahl digestion. Duplicate samples from each plot were used to determine the precision of the procedures. When results from the duplicate sample showed acceptable levels of precision (differences between two values $\pm 10 \%$ ), the mean values were recorded and the samples were used in further analyses.

The models proposed by Sánchez-Palomares et al. (Sánchez-Palomares et al. 1999) for interpolating climatic variables in Spain were used here to calculate climaterelated variables. These models are functions of altitude, geographical position (UTM X-Y coordinates) and the hydrographical basin or sub-basin to which each site belongs. The climatic variables estimated were: (1) mean annual and seasonal precipitation, (2) mean annual temperature, (3) mean, maximum and minimum temperatures in the warmest and coldest months, (4) summer temperature and temperature fluctuation, (5) duration of drought (drought interval), measured as the number of months without rainfall, (6) number of cold months, (7) sum of the 12-monthly potential evapotranspiration, (8) maximum real evapotranspiration, (9) surplus moisture and annual moisture deficit, (10) physiological drought, (11) annual calculate drainage, (12) vegetative period, (13) Vernet index and index of annual water reserve. Physiographic variables (slope, aspect and altitude) were recorded in the field inventory.

Summary statistics, including the mean (and standard deviation), minimum and maximum values of the main plot characteristics and foliar nutritional status are shown in Table 1.

\subsection{Statistical analysis}

The CHAID (Chi-squared Automatic Interaction Detector) method was used in order to determine the interaction between SI and the available qualitative and quantitative variables (climatic, edaphic, topographic and foliar nutrient variables). CHAID is an algorithm that splits a data set into segments that differ with respect to the response variable
(Kass 1980). The segments are defined by a tree structure of a number of independent variables, the predictors.

The CHAID method is an alternative to CaRT (classification and regression trees) analysis for analyzing predictiontype problems on the basis of a set of categorical or continuous predictor variables. The CHAID uses a different algorithm (than CaRT) to determine a final hierarchical classification tree in which each node can produce multiple branches (unlike CaRT, in which all nodes are binary).

When dealing with continuous predictors, the first step in the CHAID algorithm is to create predictor categories by dividing the respective continuous distributions into a number of categories with approximately equal numbers of observations. It subsequently determines the pair of predictor categories that is least significantly different with respect to the dependent variable. When the dependent variable is continuous, the $F$ test is used to determine the statistical significance (Hill and Lewicki 2006). The CHAID merges those categories of a predictor that are homogeneous with respect to the dependent variable, but maintains all categories that are heterogeneous. Since more than two categories of a predictor may differ significantly, the CHAID merging process does not necessary produce dichotomous categories.

The CHAID algorithm only splits the data for a specific predictor if this leads to a significant difference in the distribution of the dependent variable. In this way, the sampling variability in the data is taken into consideration. Furthermore, the $F$ test of independence, used to decide which categories of each predictor to merge and which predictor to split, is a non-parametric procedure as no assumptions about the data distribution need to be made (Van Diepen and Franses 2006).

The result of the CHAID algorithm is a decision tree structure with a split at each node. The final nodes - called leaves - are defined as combinations of the predictor variables (Van Diepen and Franses 2006).

In the present study, SPSS software (SPSS 2007) was used to carry out the analysis. A significance level of $5 \%$ was used in the $F$ test, the maximum number of levels was established as three, and the minimum number of cases in a node for being a child node was established in four plots. Assessment of the adequacy of the regression trees was made by means of the standard error of the estimate (SEE) statistic.

Alternatively, stepwise regression was used to derive parametric models for predicting site index. The general formulation of the parametric models is as follows:

$\mathrm{SI}=\beta_{0}+\beta_{1} \cdot \chi_{1}+\ldots+\beta_{n} \cdot \chi_{n}+\varepsilon$

where SI is the site index (dominant height at a reference age of 20 years), $\chi_{1}, \ldots, \chi_{n}$ are the explanatory variables, $\beta_{1}, \ldots, \beta_{n}$ are the unknown parameters, and $\varepsilon$ is the error term. 
Table 1 Summary of the main characteristics of the Maritime pine plots under study

\begin{tabular}{|c|c|c|c|c|c|}
\hline Variables & Code & Min. & Max. & Mean & Standard Deviation \\
\hline \multicolumn{6}{|l|}{ Stand } \\
\hline Stand age (years) & $t$ & 8.00 & 61.50 & 29.28 & 14.38 \\
\hline Dominant height (m) & $H_{0}$ & 5.50 & 30.60 & 15.72 & 6.01 \\
\hline Site index ( $m$ at 20 years age) & SI & 7.80 & 19.30 & 11.83 & 2.18 \\
\hline Stocking density (stems $\mathrm{ha}^{-1}$ ) & SD & 362.00 & $2,175.00$ & $1,032.10$ & 441.31 \\
\hline \multicolumn{6}{|l|}{ Foliar nutrient } \\
\hline Nitrogen $\left(\mathrm{mg} \mathrm{g}^{-1}\right)$ & $\mathrm{FN}$ & 9.42 & 48.34 & 19.7 & 7.86 \\
\hline Phosphorus (mg g $\mathrm{g}^{-1}$ ) & FP & 0.43 & 1.66 & 0.76 & 0.23 \\
\hline Potassium (mg g $\left.{ }^{-1}\right)$ & FK & 0.67 & 2.92 & 1.69 & 0.61 \\
\hline Calcium (mg g $\left.{ }^{-1}\right)$ & $\mathrm{FCa}$ & 0.45 & 5.33 & 2.97 & 1.04 \\
\hline Magnesium (mg g $\left.{ }^{-1}\right)$ & $\mathrm{FMg}$ & 0.23 & 0.81 & 0.44 & 0.11 \\
\hline \multicolumn{6}{|l|}{ Edaphic } \\
\hline Soil depth (m) & Depth & 0.20 & 1.30 & 0.41 & 0.21 \\
\hline Clay $(\%)$ & Clay & 4.41 & 39.84 & 18.99 & 8.39 \\
\hline Sand $(\%)$ & Sand & 45.38 & 93.38 & 74.8 & 10.22 \\
\hline Silt $(\%)$ & Silt & 2.21 & 29.13 & 7.69 & 5.05 \\
\hline Organic matter $(\%)$ & $\mathrm{OM}$ & 1.45 & 10.96 & 4.73 & 2.14 \\
\hline $\mathrm{pH}$ (water 1:1) & $\mathrm{pH}$ & 3.46 & 4.95 & 4.20 & 0.39 \\
\hline Total N (\%) & $\mathrm{N}$ & 0.04 & 0.92 & 0.28 & 0.18 \\
\hline $\mathrm{C} / \mathrm{N}$ ratio & $\mathrm{C} / \mathrm{N}$ & 4.29 & 33.51 & 12.74 & 7.41 \\
\hline Electric conductivity $\left(\mathrm{dS} \mathrm{m}^{-1}\right)$ & $\mathrm{EC}$ & 0.08 & 0.03 & 0.23 & 0.05 \\
\hline Available P Mehlich $3\left(\mathrm{mg} \mathrm{kg}^{-1}\right)$ & PM3 & 0.24 & 9.28 & 3.05 & 1.98 \\
\hline Extractable $\mathrm{K}\left(\mathrm{cmol}_{\mathrm{c}} \mathrm{kg}^{-1}\right)$ & $\mathrm{K}$ & 0.002 & 0.12 & 0.04 & 0.03 \\
\hline Extractable $\mathrm{Ca}\left(\mathrm{cmol}_{\mathrm{c}} \mathrm{kg}^{-1}\right)$ & $\mathrm{Ca}$ & 0.06 & 2.93 & 1.01 & 0.66 \\
\hline Extractable $\mathrm{Mg}\left(\mathrm{cmol}_{\mathrm{c}} \mathrm{kg}^{-1}\right)$ & $\mathrm{Mg}$ & 0.04 & 0.76 & 0.20 & 0.14 \\
\hline Extractable $\mathrm{Al}\left(\mathrm{cmol}_{\mathrm{c}} \mathrm{kg}^{-1}\right)$ & $\mathrm{Al}$ & 1.19 & 23.13 & 6.38 & 3.64 \\
\hline Effective cation exchange capacity $\left(\mathrm{cmol}_{\mathrm{c}} \mathrm{kg}^{-1}\right)$ & ECEC & 1.96 & 25.36 & 7.93 & 3.65 \\
\hline \multicolumn{6}{|l|}{ Physiographic } \\
\hline Slope $(\%)$ & Slope & 0.00 & 70.00 & 38.70 & 16.08 \\
\hline Elevation $(\mathrm{m})$ & Elev & 64.00 & 728.00 & 410.57 & 178.75 \\
\hline \multicolumn{6}{|l|}{ Climatic } \\
\hline Annual total precipitation (mm) & $\mathrm{TP}$ & 972.00 & $1,216.00$ & $1,066.10$ & 73.12 \\
\hline Spring precipitation $(\mathrm{mm})$ & SP & 240.00 & 306.00 & 263.23 & 18.61 \\
\hline Summer precipitation (mm) & $\mathrm{SuP}$ & 134.00 & 189.00 & 143.78 & 10.27 \\
\hline Autumn precipitation (mm) & $\mathrm{AP}$ & 277.00 & 369.00 & 298.45 & 20.82 \\
\hline Winter precipitation (mm) & WP & 310.00 & 432.00 & 360.61 & 34.87 \\
\hline Mean annual temperature $\left({ }^{\circ} \mathrm{C}\right)$ & MAT & 10.30 & 13.30 & 11.72 & 0.81 \\
\hline Mean temperature of the warmest month $\left({ }^{\circ} \mathrm{C}\right)$ & MTWM & 16.50 & 19.00 & 17.63 & 0.55 \\
\hline Mean temperature of the coldest month $\left({ }^{\circ} \mathrm{C}\right)$ & MTCM & 4.70 & 8.80 & 6.64 & 1.14 \\
\hline Temperature fluctuation $\left({ }^{\circ} \mathrm{C}\right)$ & TA & 17.00 & 24.00 & 20.36 & 1.61 \\
\hline Maximum mean temperature of the warmest month $\left({ }^{\circ} \mathrm{C}\right)$ & MMTWM & 22.00 & 24.90 & 23.10 & 0.74 \\
\hline Minimum mean temperature of the coldest month $\left({ }^{\circ} \mathrm{C}\right)$ & MMTCM & 0.60 & 5.00 & 2.74 & 1.14 \\
\hline Evapotranspiration (mm) & ETP & 635.00 & 709.00 & 669.96 & 19.53 \\
\hline Annual moisture surplus (mm) & $\mathrm{TS}$ & 431.00 & 722.00 & 548.45 & 81.80 \\
\hline Annual moisture deficit (mm) & $\mathrm{PD}$ & 118.00 & 172.00 & 152.30 & 11.02 \\
\hline Annual water reserve index & AWRI & 48.30 & 100.50 & 68.55 & 14.20 \\
\hline Drought interval (months) & DI & 0.00 & 0.70 & 0.28 & 0.16 \\
\hline Physiological drought (mm) & $\mathrm{PhD}$ & 21.00 & 70.00 & 49.32 & 12.87 \\
\hline Annual calculated drainage (mm) & ACDRA & 309.00 & 631.00 & 445.46 & 83.06 \\
\hline
\end{tabular}


Table 1 (continued)

\begin{tabular}{llllll}
\hline Variables & Code & Min. & Max. & Mean & Standard Deviation \\
\hline Maximum real evapotranspiration (mm) & MRE & 585.00 & 688.00 & 620.59 & 23.05 \\
Colds months number (months) & CMN & 0.00 & 3.00 & 0.61 & 1.05 \\
Vegetative period (months) & VP & 8.00 & 12.00 & 10.45 & 1.08 \\
Mean summer temperature $\left({ }^{\circ} \mathrm{C}\right)$ & MST & 15.50 & 18.20 & 16.71 & 0.57 \\
Mean winter temperature $\left({ }^{\circ} \mathrm{C}\right)$ & MWT & 5.20 & 9.10 & 6.70 & 1.04 \\
Vernet index & VI & -4.40 & -1.80 & -3.11 & 0.52 \\
\hline
\end{tabular}

Note: the main characteristics of the aspect variable are: north (7.3\% of plots): northeast (7.3\%); northwest (17.1\%); east (3.7\%); south (20.7\%); southeast (11.0\%); southwest (17.1\%) and west $(7.3 \%)$

Two different types of parametric models were developed: (i) the best models considering each of the four types of variables available separately, and (ii) the best model, including all the available variables as potential regressors. The significance level for entering variables in the model and retaining them was set at 0.01 .

The criteria used to evaluate the adequacy of both types of parametric models were the adjusted coefficient of determination $\left(R^{2}{ }_{\text {adj }}\right)$ and the standard error of the estimate (SEE), also referred to as the root mean squared error.

The best parametric model was applied to the systematic network of plots $(1 \times 1 \mathrm{~km})$ in the Spanish National Forest Inventory (DGCN 2006), and geostatistical approaches were used to develop maps showing the capacity of the region for growing maritime pine. The method used was ordinary kriging, which relies on the spatial correlation structure of the data to determine the weighting values of nearby data points. According to previous studies, this geostatistical approach accurately reproduces the spatial distribution and variability in site index (e.g., Tang and Bian 2009).

\section{Results}

\subsection{Regression trees}

\subsubsection{Foliar nutrients and soil characteristics}

The CHAID procedure revealed that site index is significantly related to foliar phosphorus concentrations $(P$-value $=0.018)$ (Fig. 3), with the highest concentrations of $\mathrm{P}$ related to the highest site index values. The mean SI in stands with $\mathrm{P}$ concentrations below or equal to $0.80 \mathrm{~g} / \mathrm{kg}$ was $11.4 \mathrm{~m}$, whereas the mean SI in stands with $\mathrm{P}$ concentrations above $0.80 \mathrm{~g} / \mathrm{kg}$ was $13.1 \mathrm{~m}$.

With regard to soil parameters, soil depth is the first explanatory variable in the CHAID procedure (Fig. 4), i.e., it is the main soil-related variable that limits height growth of the stands in Asturias. In this case, three groups were found to be statistically significant: shallow soils $(<25 \mathrm{~cm}$ depth), which implies a mean SI of the stand of $10.5 \mathrm{~m}$, soils of intermediate depth $(25-67 \mathrm{~cm}$ depth), with a mean SI of $11.8 \mathrm{~m}$ for the stand, and deep soils $(>67 \mathrm{~cm}$ depth), for which the highest mean SI (14.6 m) was obtained.
Fig. 3 Regression tree in which the CHAID algorithm is used for foliar nutrient variables

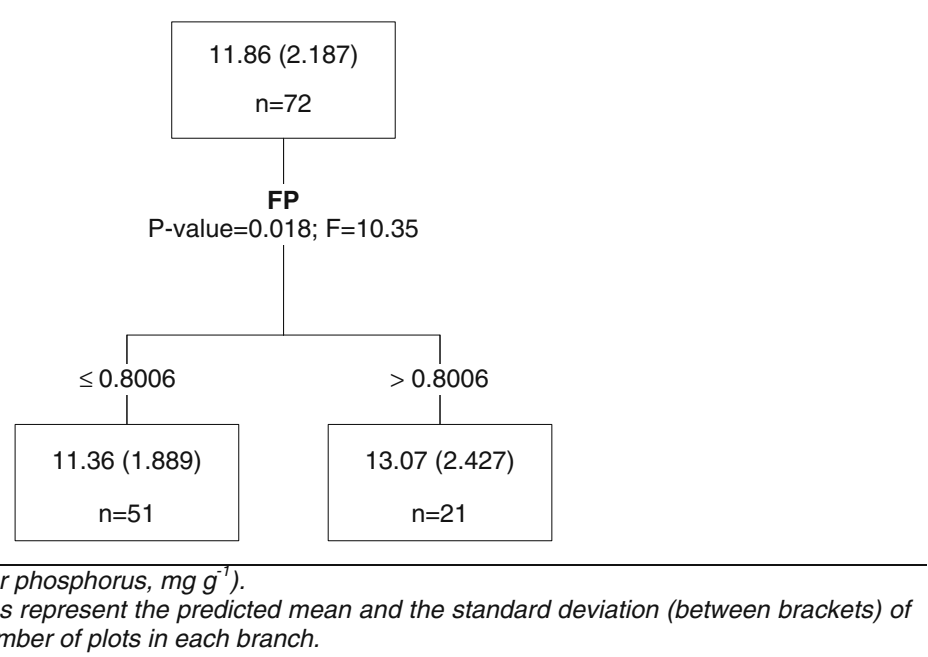


Fig. 4 Regression tree in which the CHAID algorithm is used for soil variables

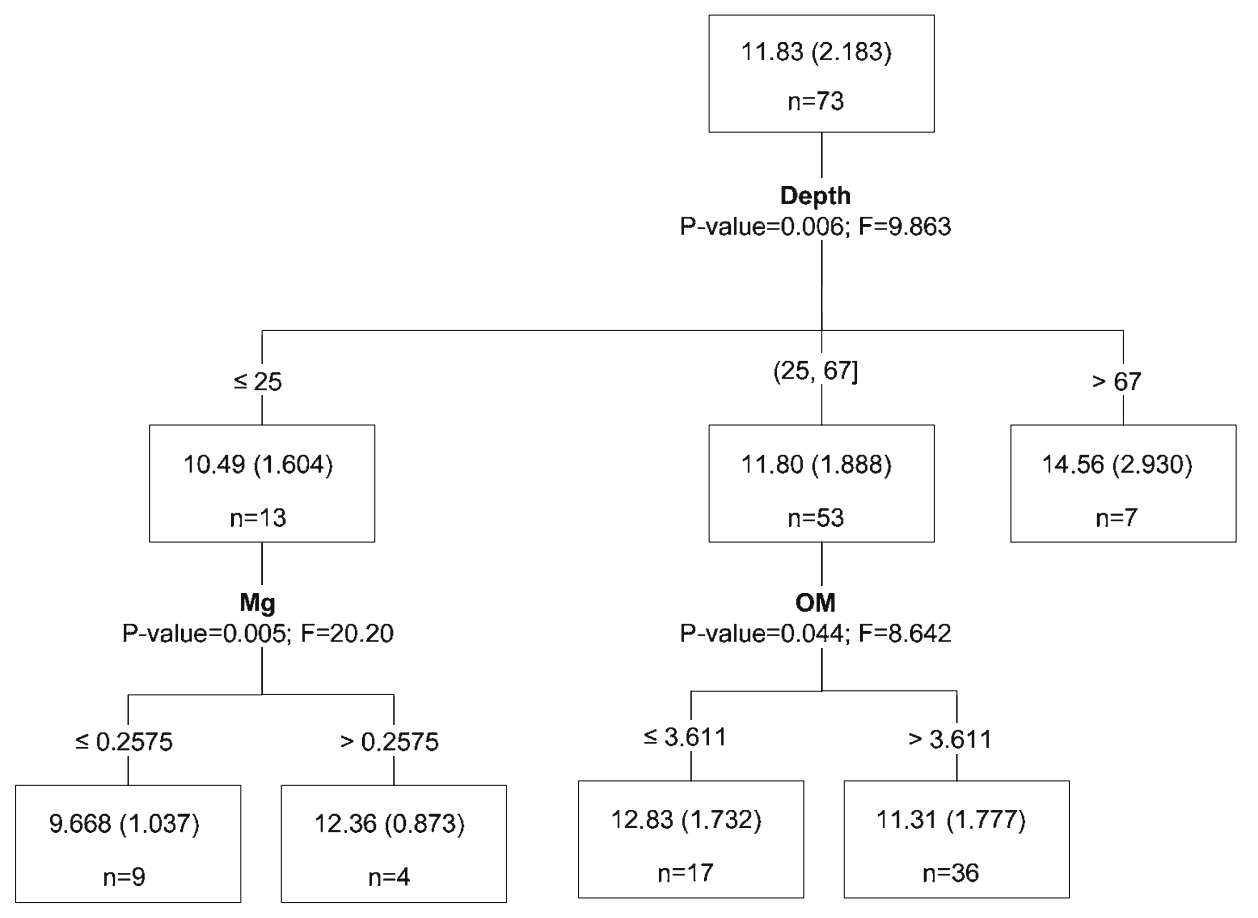

Significant variables: Depth (soil depth, $\mathrm{cm}$ ), $\mathrm{Mg}$ (Magnesium content, $\mathrm{cmol}_{\mathrm{c}} \mathrm{kg}^{-1}$ ), OM (Organic matter content, \%). See Fig. 3 legend for interpretation of the regression tree model.
At the second level, $\mathrm{Mg}$ was the most decisive element $(P$-value $=0.005)$ in explaining height growth in shallower soils $(<25 \mathrm{~cm})$, and concentrations above $0.257 \mathrm{cmol}_{\mathrm{c}} \mathrm{kg}^{-1}$ produced marked increases in height growth. In intermediate soils (25-67 cm soil depth), significant differences in height growth of stands were related to the organic matter content: the site index was higher in stands with organic matter content less than or equal to $3.61 \%$ than in stands in which the organic matter content exceeded this value.

The standard error of the estimate was $2.06 \mathrm{~m}$ and $1.72 \mathrm{~m}$ for foliar nutrients and soil regression trees respectively.

\subsubsection{Physiographic and climatic conditions}

Elevation is the physiographic variable that plays the most important role in the height growth of maritime pine in the region (Fig. 5); two significant groups were established on this basis $(P$-value $=0.048)$ : one for low elevations $(<513 \mathrm{~m})$ with a mean SI of $12.3 \mathrm{~m}$ for the plots, and the other for stands in elevations above $513 \mathrm{~m}$, for which the site index was lower $(10.8 \mathrm{~m})$.

With regard to climatic variables, it can be observed that the mean summer temperature (MST) had a positive effect
Fig. 5 Regression tree in which the CHAID algorithm is used for physiographic variables

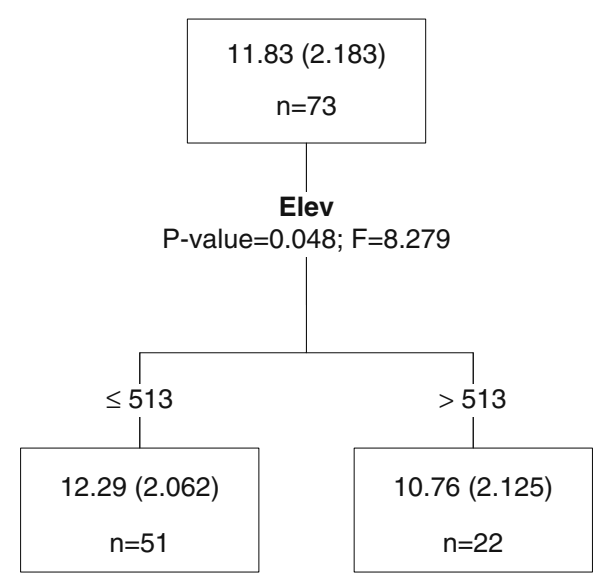

Significant variables: Elev (Elevation, $m$ ). See Fig. 3 legend for interpretation of the regression tree model. 
on height growth (Fig. 6). The CHAID procedure established two groups for this variable: one with a mean temperature above $17.2^{\circ} \mathrm{C}$, which corresponds to a mean site index of $13.8 \mathrm{~m}$, and other where the MST is below $17.2^{\circ} \mathrm{C}$, with a mean site index of $11.3 \mathrm{~m}$. The latter was split into two other significantly different groups $(P$-value $=0.005)$ associated with winter precipitation (WP), in which plots with WP $\leq 393 \mathrm{~mm}$ had a higher site index $(11.8 \mathrm{~m})$ than plots with higher precipitation (mean $\mathrm{SI}=9.9 \mathrm{~m}$ ).

The standard error of the estimate was $2.09 \mathrm{~m}$ and $1.87 \mathrm{~m}$ for physiographic and climatic regression trees respectively.

\subsubsection{All variables available}

The regression tree including all the different types of environmental and foliar nutrient factors (Fig. 7) provides an overall picture of the relative importance of the variables. Both the first and second splitter variables are identical to those obtained in the separate analyses of soilrelated variables: soil depth, $\mathrm{Mg}$ and organic matter content. The only difference is the inclusion of a third split level, defined by the mean annual temperature (MAT) for concentrations of $\mathrm{Mg}$ below $0.257 \mathrm{cmol}_{\mathrm{c}} \mathrm{kg}^{-1}$. The standard error of the estimate for this regression tree was $1.71 \mathrm{~m}$.

\subsection{Parametric regression models}

Parametric regression models were fitted separately for each group of variables (foliar nutrients and physiographic, edaphic, climatic variables), and for all variables together (the "best" parametric model). The fitted equations and the values of the goodness-of-fit statistics are shown in Table 2.

The variables selected by the stepwise regression were the same as those constituting the first level of branches of the CHAID. Variables related to foliar nutrients and physiographic conditions (Models 1 and 2) accounted for a lower percentage of total variability than those related to soil and climate (soil depth and mean summer temperature, respectively) (Models 3 and 4).

As expected, the model that explained the highest percentage of variability in SI $(45 \%)$ was obtained by combining different types of variables. Soil depth and mean summer temperature are predictors in the "best" parametric model (Model 5). No physiographic or foliar nutrient variables were found to be significant.

\section{Discussion}

\subsection{Regression trees}

\subsubsection{Foliar nutrients and soil characteristics}

The CHAID and parametric regression analysis both revealed that foliar $\mathrm{P}$ concentration is directly related to height growth. This is not surprising, since phosphorus is an important macronutrient for all plants. Some authors (e.g., Dumbrell and McGrath 2002) have also reported strong
Fig. 6 Regression tree in which the CHAID algorithm is used for climatic variables

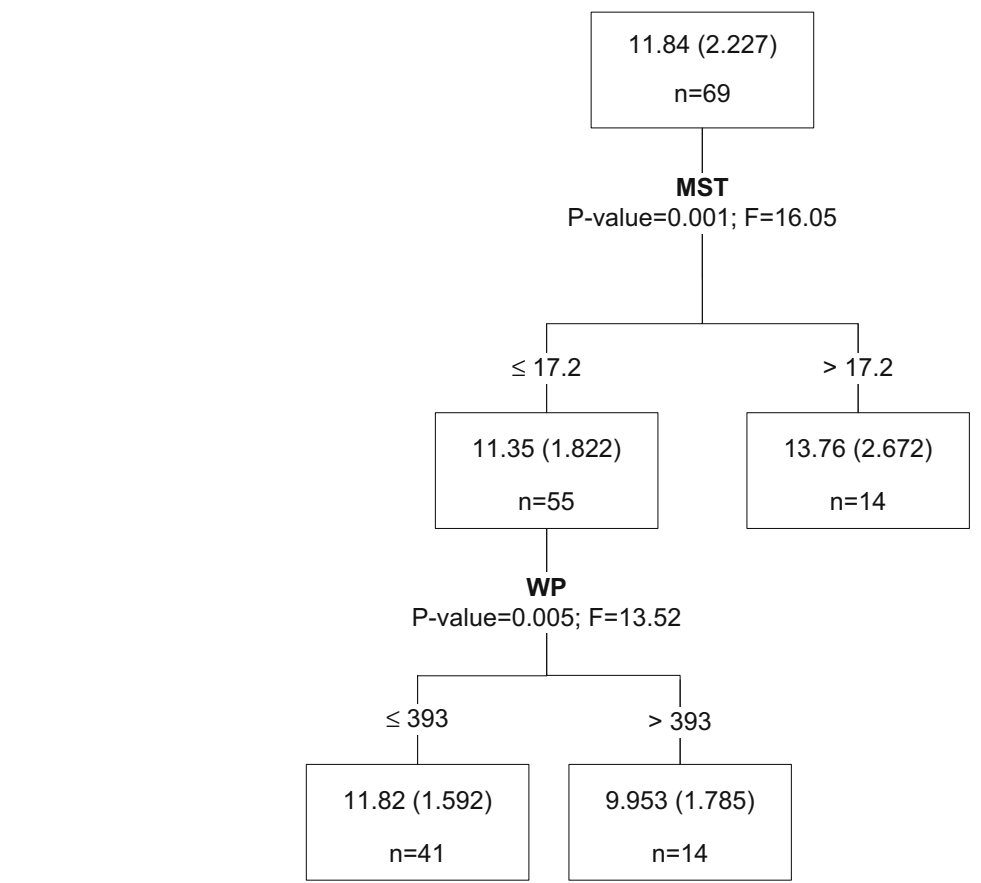

Significant variables: MST (Mean summer temperature, ${ }^{\circ} \mathrm{C}$ ); WP (Winter precipitation, $\mathrm{mm}$ ). See Fig. 3 legend for interpretation of the regression tree model. 
Fig. 7 Regression tree in which the CHAID algorithm is used for all the variables available

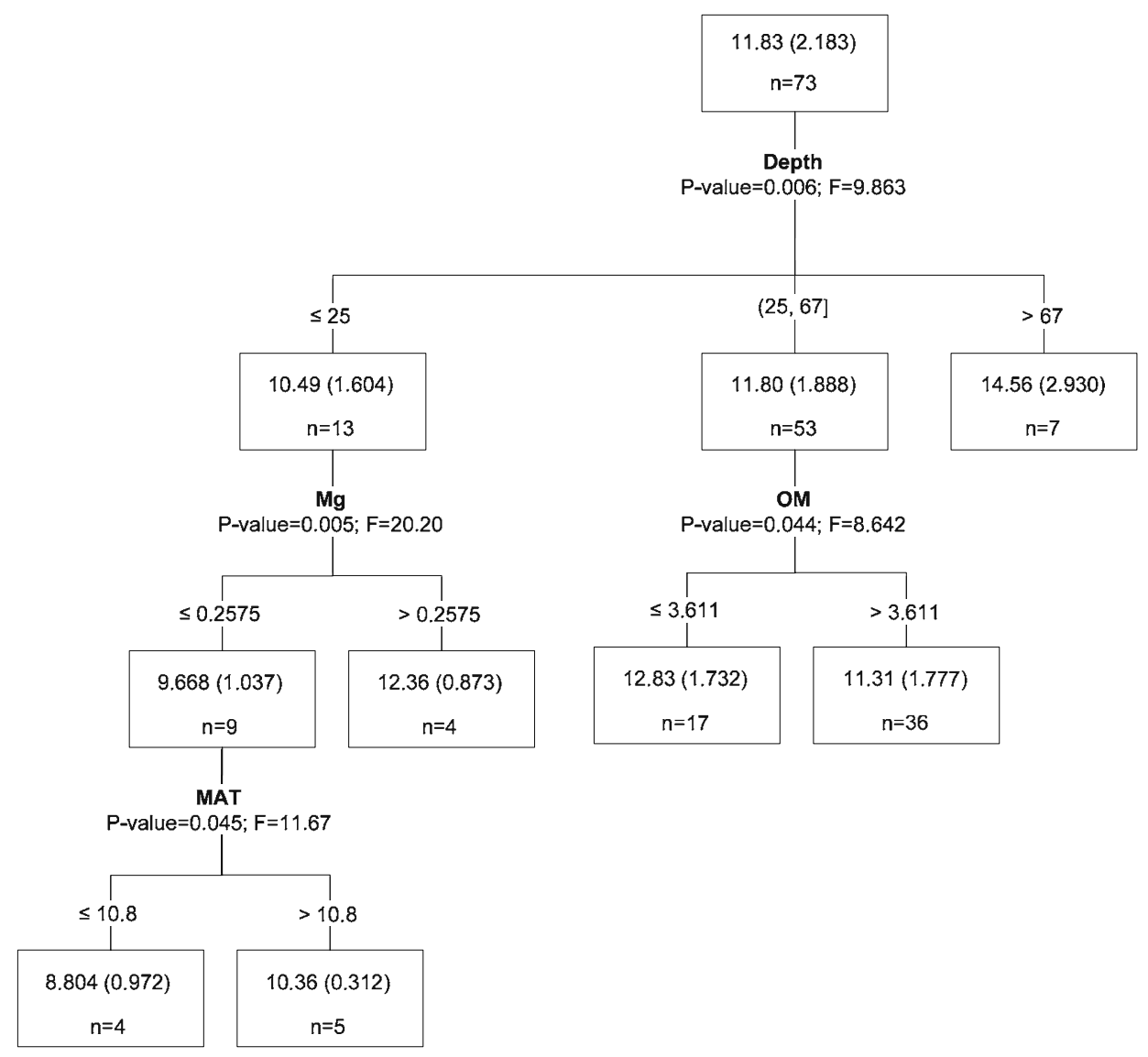

Significant variables: Depth (soil depth, $\mathrm{cm}$ ), $\mathrm{Mg}$ (Magnesium content, $\mathrm{cmol}_{\mathrm{C}} \mathrm{kg}^{-1}$ ), OM (Organic matter content, $\%$ ) and MAT (Mean annual temperature, ${ }^{\circ} \mathrm{C}$ ). See Fig. 3 legend for interpretation of the regression tree model. relationships between growth and foliar phosphorus content in Pinus pinaster. These authors also showed that there is a negative interaction between $\mathrm{N}$ and $\mathrm{P}$, so that application of $\mathrm{N}$ in combination with $\mathrm{P}$ in soils reduces the concentration of foliar $\mathrm{P}$ and reduces height growth significantly.

According to the values of satisfactory levels of foliar nutrients reported by Bará (1991) and Bonneau (1995) for maritime pine in Spain and France respectively (Table 3), the stands in the present study are clearly deficient in $\mathrm{K}$, $\mathrm{Mg}$ and $\mathrm{P}$. Moreover, the values obtained for these macro- nutrients are even lower than the marginal levels used as reference values for the nutritional status of the species (Table 3). This is consistent with the results reported by López et al. (2008) for the nearby region of Galicia, although concentrations of $\mathrm{K}, \mathrm{Mg}$ and $\mathrm{P}$ were higher than those found in Asturias, probably because the stands analyzed were young plantations on abandoned agricultural land with different levels of fertilization.

In relation to soil parameters, soil depth was the most important variable for estimating SI. This is consistent with

Table 2 Parametric models for estimation of SI in Maritime pine stands in Asturias (NW Spain)

\begin{tabular}{|c|c|c|c|c|}
\hline Model & Constituent variables & Fitted equation & $R_{\text {adj }}^{2}$ & $\operatorname{SEE}(\mathrm{m})$ \\
\hline 1 & Foliar nutrients & $\mathrm{SI}=9.509+3.073 \cdot \mathrm{FP}$ & 0.10 & 2.08 \\
\hline 2 & Physiographic & $\mathrm{SI}=13.82-0.004837 \cdot$ Elev & 0.15 & 2.03 \\
\hline 3 & Climatic & $\mathrm{SI}=-25.17+2.218 \cdot \mathrm{MST}$ & 0.25 & 2.01 \\
\hline 4 & Edaphic & $\mathrm{SI}=9.447+2.218 \cdot \mathrm{Depth}$ & 0.32 & 1.87 \\
\hline 5 & All variables available & $\mathrm{SI}=-10.99+1.238 \cdot \mathrm{MST}+0.05287 \cdot$ Depth & 0.45 & 1.73 \\
\hline
\end{tabular}

Note: All independent variables are significant at $P<0.05$ and all the models are significant at $P<0.001$. All variable units are the same as in Table 1 
Table 3 Range of satisfactory (S.L.) and marginal levels (M.L.) of foliar nutrients in Maritime pine (established from the values reported by Bará (1991) and Bonneau (1995) for the species in Galicia and France respectively)

\begin{tabular}{lll}
\hline Foliar nutrients & S.L. $\left(\mathrm{mg} \mathrm{g}^{-1}\right)$ & M.L. $\left(\mathrm{mg} \mathrm{g}^{-1}\right)$ \\
\hline $\mathrm{N}$ & $12.0-15.0$ & $10.0-12.0$ \\
$\mathrm{P}$ & $1.2-1.5$ & $0.8-1.0$ \\
$\mathrm{~K}$ & $>5.0$ & $3.0-5.0$ \\
$\mathrm{Ca}$ & $1.0-1.2$ & 1.0 \\
$\mathrm{Mg}$ & $>1.0$ & $0.7-1.0$ \\
\hline
\end{tabular}

the general idea that soil depth is related to the exploitable soil volume for the roots and, consequently, to the available water and nutrition, and lastly to site index (Pyatt et al. 2001). Bará and Toval (1983), Maugé (1987), RodríguezSoalleiro (1995) and Carvalho Oliveira et al. (2000) have also demonstrated that the potential productivity of Maritime pine stands is primarily linked to soil depth and availability of access to a groundwater table during the growing season. Moreover, effective soil depth was used as a dependent variable for soil characterization in the development of an individual-tree growth model for Maritime pine (Schröder et al. 2002) in coastal areas of Galicia.

Among the soil nutrient factors, only $\mathrm{Mg}$ and organic matter content $(\mathrm{OM})$ were found to be significant factors in explaining SI, in relation to soil depth. In shallow soils, the concentration of $\mathrm{Mg}$ is a key soil variable, owing to synergistic effects or interactions between this variable and soil depth. Possible deficiencies in Mg in shallow soils may be the result of the rapid depletion of this nutrient, especially in areas with high precipitation, where $\mathrm{Mg}$ is fairly water-soluble and is readily leached to the lower layers of the soil. According to Tisdale et al. (1993), there is a possibility of $\mathrm{Mg}$ deficiency when this nutrient accounts for less than $10 \%$ of the cation exchange capacity of the soil, although this figure greatly depends on the soil.

Organic matter content is especially significant in moderately deep soils, and is inversely related to site index. Similar results were obtained by Rodriguez-Soalleiro (1995), who reported that the best site qualities for Maritime pine in Galicia correspond to sandy textured soils, with a lower amount of organic matter and exchangeable bases.

It may appear surprising that no other macro or micronutrients were found to be significant explanatory variables in the CHAID analysis. However, it must be taken into account that Maritime pine does not have high mineral requirements, and therefore can grow in nutrient-poor soils (e.g., Maugé 1987, Carvalho Oliveira et al., 2000). The greater interaction between effective soil depth (as compared with soil nutrients) and SI appears to indicate that Maritime pine may be considered as a "site-demanding" rather than a "nutrient-demanding" species, which is accordance with its recognized frugality. This frugality may be related to the fact that the fungi that commonly form the mycorrhizae prosper best in soils of $\mathrm{pH}$ less than or equal to 5 (Maugé 1987).

\subsubsection{Physiographic and climatic conditions}

It is widely accepted that climatic and physiographic conditions of seed origin play an important role in the genetic variation of Maritime pine (Alía et al. 1997). However, the relationship between climatic and physiographic conditions and height growth has not been wellstudied in this species.

Although Maritime pine shows a wide ecological tolerance, elevation greatly affects growth in the Spanish area of distribution (Nicolas and Gandullo 1967) and at a regional level. For instance, in Galicia, Rodríguez-Soalleiro (1995) found a significant relationship between altitude and SI, and established two levels for this variable $(0-400 \mathrm{~m})$ and $(>400 \mathrm{~m})$, similar to those established by the CHAID procedure for Asturias.

With regard to the relationship between climate conditions and SI, mean summer temperature (MST) and winter precipitation (WP) were found to be highly significant for explaining site index in Asturias. MST had a positive effect on height growth, unlike in Mediterranean areas of Spain where temperature during the growth season had a negative effect.Nevertheless, it must be taken into account that in Asturias the climate is characterized by milder and less variable (intra-annually) temperatures than in Mediterranean areas of central Spain and Portugal. Under such environmental conditions, summer temperature influences the rates of organic matter mineralization and nutrient uptake by plant roots, and therefore controls nutrient availability to plants. In addition, summer precipitation is usually higher than $130 \mathrm{~mm}$ in the study site (Table 1), which implies that there is no important climatic restriction for growth in the summer period.

On the other hand, high values of WP did not promote height growth in Maritime pine in Asturias. This may appear surprising, since precipitation is a crucial factor in explaining the spatial variation in SI in Mediterranean areas (e.g., Gaspar et al. 2009). However, it must be taken into account that for the generally wet conditions in the region, high WP may be unfavourable, because it favours rapid depletion of water-soluble nutrients.

\subsection{Parametric regression models}

According to the parametric regression models obtained from the different types of variables (Models 1-4, Table 2), edaphic and climatic variables (represented by effective soil 
depth and mean summer temperature respectively) account for most of the variation in SI. In fact, these two variables were selected by the stepwise procedure including all the available variables, and explained $45 \%$ of the variation in SI (Model 5, Table 2).

Some authors have found better performance for SI prediction with other species (e.g., Chen et al. (1998) for Trembling aspen, Fontes et al. (2003) for Douglas fir in Portugal, Romanyà and Vallejo (2004) for Pinus radiata in Spain, etc.). Nevertheless, when comparing this type of outcome, the following two aspects should be considered: (i) Maritime pine presents a highly complex genetic structure with large genetic differences among populations (e.g., Alía et al. 1997; Salvador et al. 2000; GonzálezMartínez et al. 2004), and (ii) in the present study, only robust statistical models with just one or two predictor variables were selected.

With regard to the first aspect, it is important to emphasize that several Maritime pine provenances were used in the plantations in Asturias, because until recently there was no local provenance available. Most of the aged stands are reforestations in which the seed origin is unknown (Catalán 1988) (although they possibly originate from Atlantic and Central areas of Spain), whereas many of the recent plantations are derived from French provenances. The high levels of genetic diversity and an important genotype-by-environment interaction favour the existence of adaptations to local ecological conditions and different growth patterns. González-Martínez et al. (2004) have found that the provenance factor explains a substantial amount of the variance in SI (in some cases approximately $30 \%$ ).

With regard to the second aspect, a slightly higher percentage of variability in SI in the Maritime pine stands was explained in other studies in which less robust models were used. For instance, Pacheco Marques (1991) explained $54.4 \%$ of the variability in SI in Portuguese Maritime pine stands with four regressor variables: minimum temperature in autumn, available potassium, total porosity and fine sand content.

Furthermore, other factors not considered in this study may also affect site productivity, e.g., some silvicultural practices such as weed control, competition from understory vegetation, etc.

In the separate analyses of the variables, the predictors selected by the stepwise regression were the same as those constituting the first split level in the regression trees. The results confirm the relative importance of these variables in explaining the site index. Additionally, regression tree models showed a very similar average squared error than the parametric regression models in predicting SI.

In the analysis of all variables, the variables selected by both procedures were not exactly the same. Soil depth is a significant variable in both types of analysis, whereas MST was not included in the regression tree, and MAT was included in a third split level in the regression tree. These results clearly indicate that soil depth is a key factor limiting height growth. The observed differences between the two procedures can be attributed to their different inherent structure. In the hierarchical structure of the
Fig. 8 Maps of spatial distribution of SI for Maritime pine in Asturias, according to the best model developed
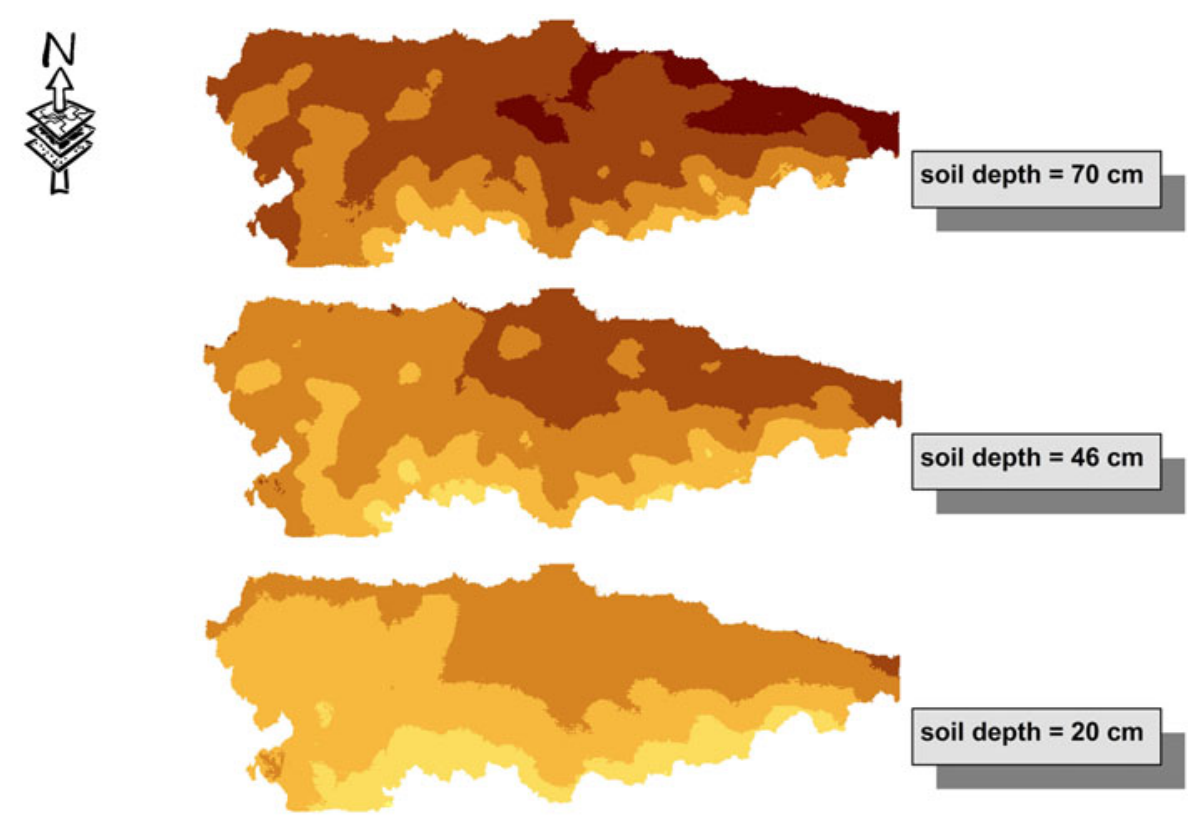

SITE INDEX $\backsim 6.80-7 \quad \sum 7.01-9 \quad \sum 9.01-11 \quad 311.01-13$ $13.01-15$ $15.01-20$ 
decision trees, the independent variables are considered sequentially, revealing the order of importance of the variables in explaining SI, i.e., the variable selected first is more important than those selected subsequently. On the contrary, the stepwise procedure considers all variables simultaneously, i.e., it does not create subgroups and identifies the most important independent variable in each subgroup.

Predictive SI maps were developed on the basis of Model 5 (Table 2) and the systematically sampled plots in the Third National Forest Inventory for the region. Values of mean summer temperature (MST) for each plot were determined using the model proposed by SánchezPalomares et al. (Sánchez-Palomares et al. 1999). Three scenarios of soil depth were considered on the basis of the mean predicted values corresponding to the first level of branches of the CHAID regression tree. Analysis of the predictive maps (Fig. 8) revealed that the most favourable area for Maritime pine growth is concentrated in the central and eastern cost of this region, where temperatures are higher in summer and precipitation is lower in winter than in western areas. This map may be useful for selecting the most suitable areas for afforestation with this species and for predicting forest growth.

\section{Conclusions}

The productivity of any vascular plant decreases when an environmental factor is outside the optimum range for growth. Bearing this in mind, the aim of the present study was to determine the relationship between productivity (evaluated by site index) and several environmental conditions in Maritime pine stands in Asturias, in order to determine the most suitable growth conditions for the species.

For this purpose, two different statistical analyses were carried out: the non-parametric CHAID procedure and parametric regression analysis. The CHAID procedure was found to be a powerful alternative tool to other methods such as principal component analysis or discriminant rules for determining the key factors that affect stand growth.

Regression trees enable visual evaluation of the results of the CHAID algorithm and a good understanding of the influence of complex interactions among predictor variables on the SI sequentially. These interactions may result in compensatory effects that may mask the influence of a certain variable when several are analysed.

Interestingly, the variables selected in the first split level of the regression trees obtained from the CHAID algorithm were the same as those obtained in the stepwise parametric regression, for the four types of variables studied. This concordance makes the process of selecting the variables that have the greatest influence on site index more consistent.

According to parametric regression models, a physical soil characteristic (soil depth) was found to be the most important factor for explaining the productivity of Maritime pine in the region, followed by a climatic characteristic (mean summer temperature). The best site qualities were observed in plots with deep soils and high summer temperatures. Although the percentage of variability in SI explained by these variables is slightly less than $50 \%$, it must be taken into account that the provenance factor can describe a substantial percentage of the unexplained variability in SI.

The results obtained in the present study provide further knowledge about the ecology of this species in Asturias, and comprise an important tool in forest management, especially for afforested areas and in scenarios where timber production is the primary objective.

Acknowledgements Funding for this research was provided by the Spanish Ministry of Science and Innovation, project No AGL2008$02259 / F O R$ and the local government of the Asturias Region, project No CN-07-094. We thank Dr. Christine Francis for correcting the English grammar of the text.

\section{References}

Alía R, Moro J, Denis JB (1997) Performance of Pinus pinaster provenances in Spain: interpretation of the genotype by environment interaction. Can J For Res 27:1548-1559

Bará S (1991) Fertilización forestal. Colección Técnica. Consellería de Agricultura, Ganadería y Montes, Xunta de Galicia, Santiago de Compostela, España, 143 pages

Bará S, Toval G (1983) Calidad de estación de Pinus pinaster Ait. en Galicia. Serie Recursos Naturales 24. Comunicaciones INIA, Madrid, 166 pages

Barrio M, Castedo F, Diéguez-Aranda U, Álvarez JG, Parresol BR, Rodríguez R (2006) Development of a basal area growth system for maritime pine in northwestern Spain using the generalized algebraic difference approach. Can J For Res 36:1461-1474

Battaglia M, Sands P (1997) Modelling site productivity of Eucalyptus globulus in response to climatic and site factors. Aust J Plant Physiol 24:831-850

Bonneau M (1995) Fertilisation des forêts dans les pays tempérés. ENGREF, Nancy, 368 pages

Carvalho Oliveira A, Santos PJ, Vaz CA (2000) A selvicultura do pinheiro bravo. Centro Pinus, Portugal, 111 pages

Catalán G (1988) La producción de semilla en los programas de mejora genética. In: Pardos JA (eds) Mejora genética de especies arbóreas forestales. Fundación Conde del Valle de Salazar, Madrid, pp 149-160

Chen HYH, Klinka K, Kabzems RD (1998) Site index, site quality, and foliar nutrients of trembling aspen: relationships and predictions. Can J For Res 28:1743-1755

Cieszewski CJ, Harrison M, Martin SW (2000) Practical methods for estimating non-biased parameters in selfreferencing growth and yield models. University of Georgia, Athens, PMRC-TR 2000-7 
Clutter J, Fortson J, Pienaar L, Brister H, Bayley R (1983) Timber management: a quantitative approach. John Wiley \& Sons, New York, p 333

DGCN (2006) Tercer Inventario Forestal Nacional. Principado de Asturias. Ministerio de Medio Ambiente, Madrid, 439 pages

Dumbrell IC, McGrath JF (2002) Growth and nutrient relationships of juvenile Pinus pinaster grown on ex-farmland in Western Australia. Aust For 66:137-144

Fontes L, Tomé M, Thompson F, Yeomans A, Sales LJ, Savill P (2003) Modelling the Douglas-fir (Pseudotsuga menziesii (Mirb.) Franco) site index from site factors in Portugal. Forestry 76:491-507

Gaspar MJ, Lousada JL, Rodrigues JC, Aguiar A, Almeida MH (2009) Does selecting for improved growth affect wood quality of Pinus pinaster in Portugal? For Ecol Manage 258:115-121

Gee GW, Bauder JW (1996). Particle size analysis. In: Klute A (eds) Methods of soil analysis, part 1, 2nd ed. American Society of Agronomy, Madison, pp 383-411

González-Martínez SC, Mariette S, Ribeiro MM, Burban C, Raffin A, Chambel MR, Ribeiro CAM, Aguiar A, Plomion C, Alía R, Gil L, Vendramin GG, Kremer A (2004) Genetic resources in maritime pine (Pinus pinaster Aiton): molecular and quantitative measures of genetic variation and differentiation among maternal lineages. For Ecol Manage 197:103-115

Hill T, Lewicki P (2006) Statistics: methods and applications: a comprehensive reference for science, industry, and data mining. StatSoft Inc.

Hossfeld JW (1822) Mathematik für Forstmänner, Ökonomen und Cameralisten (Gotha, 4. Bd., S. 310)

Jones JB, Wolf B, Mill HA (1991) Plant analysis handbook: a practical sampling preparation. Analysis and interpretation guide. Micro-Macro Publishing, Athens, p 213

Kass G (1980) An exploratory technique for investigating large quantities of categorical data. Appl Stat 29:119-127

Lebourgeois F (2007) Climatic signal in annual growth variation of silver fir (Abies alba Mill.) and spruce (Picea abies Karst.) from the French Permanent Plot Network (RENECOFOR). Ann For Sci 64:333-243

López B, Ocaña L, Lario FJ, Merino A, Rodríguez R (2008) Relación estación-producción y estado nutricional de plantaciones jóvenes de Pinus pinaster Ait. en terrenos agrícolas abandonados en Galicia. In: Pardos M, Puértolas J (eds) Cuadernos de la Sociedad Española de Ciencias Forestales 28. Sociedad Española de Ciencias Forestales, Spain, pp 237-243

MARM (2008) Anuario de estadística forestal 2007. Área de Medio Ambiente (http://www.mma.es)

Maugé J (1987) Le pin maritime. Premier résineux de France. IDF, Paris, 192 pages

Monserud RA, Moody U, Breuer DW (1990) A soil-site study for inland Douglas-fir. Can J For Res 20:686-695
Nicolas A, Gandullo J (1967) Ecología de los pinares españoles. 1, Pinus pinaster Ait. Ministerio de Agricultura, Madrid, p 311

Pacheco-Marques C (1991) Evaluating site quality of even-aged maritime pine stands in northern Portugal using direct and indirect methods. For Ecol Manage 41:193-204

Pyatt DG, Ray D, Fletcher J (2001) An ecological site classification for forestry in Great Britain. Forestry Commission Bulletin, vol 124. Forestry Commission, Edinburgh

Rayner ME (1992) Evaluation of site classifications for modelling timber yield of regrowth karri (Eucalyptus divericolor F. Muell.). For Ecol Manage 54:315-336

Rodríguez-Soalleiro R (1995) Crecimiento y producción de masas forestales regulares de Pinus pinaster Ait. en Galicia. Alternativas selvícolas posibles. Ph. D. Thesis. Escuela Técnica Superior de Ingenieros de Montes, Madrid, p 297

Romanyà J, Vallejo VR (2004) Productivity of Pinus radiata plantation in Spain in response to climate and soil. For Ecol Manage 195:177-189

Rubio A, Sánchez-Palomares O (2006) Physiographic and climatic potential areas for Fagus sylvatica based on habitat suitability indicator models. Forestry 79:439-451

Salvador L, Alía R, Agúndez D, Gil L (2000) Genetic variation and migration pathways of maritime pine (Pinus pinaster Ait.) in the Iberian Peninsula. Theor Appl Genet 100:89-95

Sánchez-Palomares O, Sánchez SF, Carretero Carrero MP (1999) Modelos y cartografía de estimaciones climáticas termopluviométricas para la España peninsular. INIA, Ministerio de Agricultura, Pesca y Alimentación, Madrid, p 192

Soil Survey Staff (1999) Soil taxonomy: a basic system of soil classification for making and interpreting soil surveys. Agricultural handbook 436, 2nd edn. United States Department of Agriculture, Natural Resources Conservation Service, Washington, p 869

SPSS (2007) SPSS for windows, Rel. 16 (1993-2007). SPSS Inc., Chicago

Schröder J, Rodríguez SR, Vega G (2002) An age-independent basal area increment model for maritime pine trees in northwestern Spain. For Ecol Manage 157:55-64

Snowdon P, Waring HD (1991) Effects of irrigation and artificial drought in the growth and health of Pinus radiata near Canberra. ACT Aust For 54:174-186

Tang D, Bian F (2009) Forest site evaluation based on GIS and kriging. First International Conference on Information Science and Engineering, ICISE, pp 2063-2067

Tisdale SL, Nelson WL, Beaton JD, Halvin JH (1993) Soil fertility and fertilizers, 5th edn. MacMillan Publishing Company, New York

Van Diepen M, Franses HP (2006) Evaluating chi-squared automatic interaction detection. Inf Syst 31:814-831 